\title{
An Improved Trans-Z-Source Inverter with Continuous Input Current and Boost Inversion Capability
}

\author{
M.S.Giridhar ${ }^{1}$, K.Subhashini ${ }^{2}$ \\ Associate Professor, Dept .of EEE, SITAMS, Chittoor, Andhra Pradesh, India ${ }^{1}$ \\ PG Student [PE], Dept of EEE, SITAMS, Chittoor, Andhra Pradesh, India ${ }^{2}$
}

\begin{abstract}
The paper deals with a new family of high boost voltage inverters which improve upon the conventional trans-Z-source inverter and trans-quasi-Z-source inverters. The improved trans-Z-source inverter (ITZI) that provides continuous input current and a higher boost voltage inversion capability. In addition the improved inverter can suppress resonant current at start up, which might destroy the device. In comparison to the conventional trans-Z-source and trans-quasi-Z-source inverters, for same transformer turn ratio, input and output voltages, the improved inverter has a higher modulation index with reduced voltage stress on the DC link, lower current stress flow on the transformer windings and diode, are validated by simulating (ITZI) in MATLAB/SIMULINK.
\end{abstract}

KEYWORDS: Z-source inverter, Trans-Z-source inverter, Shoot through mode, Voltage source inverter, Current source inverter.

\section{I.INTRODUCTION}

The Z-source inverter was proposed in [1] in order to accomplish single-stage power conversion with buck-boost abilities. In the Z-source inverter, both of the power switches in a leg can be turned on at the same time, which eliminates dead time and significantly improves the reliability while reducing the output waveform distortion. Various Z-source inverter topologies have been published in many studies which have been focused on pulse-width modulation (PWM) strategies, modelling and control [2], applications, three level neutral-point-clamped (NPC) topology. Quasi-Zsource inverters were designed to overcome the short comings of the classic Z-source inverter and have advantages such as a reduction in the passive component ratings and an improvement in input profiles.

Some papers have recently focused on improving the boost factor of the Z-source inverter by using a very high modulation index in order to achieve an improvement in the output waveform. A combination of the Z-source inverter and switched-inductor structure, called the switched-inductor Z-source inverter, provides strong step-up inversion to overcome the boost limitation of the classical Z-source inverter. In order to overcome inconvenience of inrush current suppression at start up of the switched inductor Z-source inverter, a switched inductor quasi-Z-source is proposed which provides continuous input current, reduced passive component count, reduced voltage stress on the capacitors, lower shoot-through current, and lower current stress on inductors and diodes, in comparison to the switched -inductor Z-source inverter for the same input and output voltages.

In order to improve input current profile, an inductor-capacitor-capacitor-transformer Z-source inverter (LCCT-ZSI) used one more inductor and one more capacitor in comparison with the trans-Z-source/quasi-Z-source inverters. All topologies suit for solar and fuel cell applications, since they require high voltage gain in order to match the source voltage to the line voltage.

This paper presents a novel of high step-up inverter based on the transformer to improve the input current profile and the boost inversion ability of the conventional trans-Z-source inverter/-quasi-Z-source inverter. Like the traditional Zsource inverters, the improved inverter turns on both power switches in a leg to boost the dc bus voltage. The current drawn from the DC source is continuous. In addition, the improved inverter can suppress resonant current at start up, which might destroy the devices. Both shoot-through states and transformer turn ratio can be regulated to control the boost voltage gain. Thus the output voltage can be adjusted over a wide range, and can be boosted to a higher value. 


\section{9 \\ ISSN (Print) : $2320-3765$ \\ ISSN (Online): 2278 - 8875 \\ International Journal of Advanced Research in Electrical, Electronics and Instrumentation Engineering

\author{
(An ISO 3297: 2007 Certified Organization)
} \\ Vol. 3, Issue 8, August 2014}

The Z-source converter employs a unique impedance network (or circuit) to couple the main circuit to the power source, thus providing unique features that cannot be obtained in the traditional voltage source and current source converters where a capacitor and inductor are used, respectively. The Z-source converter overcomes the conceptual and theoretical and provides a novel power concept [4]. The Z-source inverter was proposed in order to accomplish single stage power conversion with buck-boost abilities. The improved Z-source inverter used to control the speed of an induction motor. The proposed Z-source inverter (ZSI) can effectively reduce voltage stress across the capacitors in the impedance network. This reduces the voltage range of the capacitors used and also cost of the proposed topology which in turn used to control the speed of an induction motor which is used in many valuable applications.

The three phase voltage source inverter as shown in fig.1.1 in which structural DC voltage source supported by a relatively large capacitor feeds the three phase inverter circuit. The DC voltage source can be a battery, fuel cell stack, diode rectifier, and/or capacitor. Six switches are used in the main circuit each is traditionally composed of a power transistor and an anti parallel (or freewheeling) diode to provide bidirectional current flow and unidirectional voltage blocking capability.

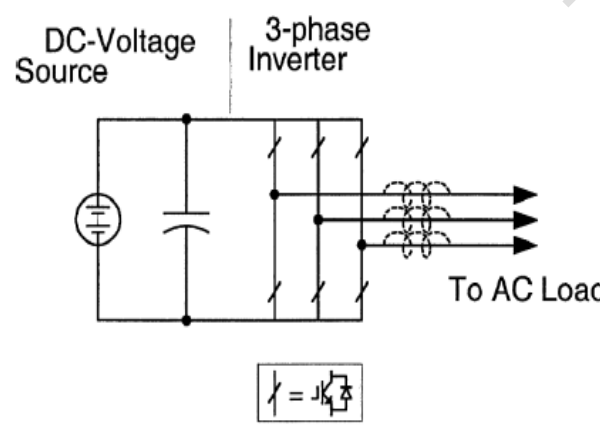

Fig.1.1 Voltage source inverter

The current source inverter as shown in fig.1.2 in which a DC current source feeds the three phase inverter circuit. The DC current source can be relatively large dc inductor fed by a voltage source such as battery, fuel cell stack, diode rectifier, or thyristor converter. Six switches are used in the main circuit each is traditionally [3].

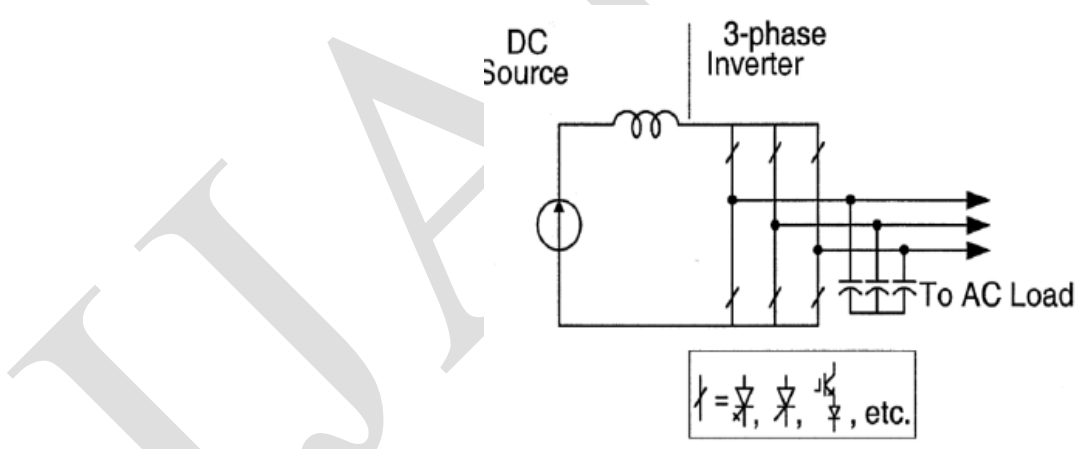

Fig.1.2 Current source inverter

Z-source inverter is the combination of voltage source inverter and current source inverter and it's general structure is shown in fig.1.3. A two port network that consists of a split-inductor L1 and L2 and capacitors C1 and C2 connected in $\mathrm{X}$ shape is employed to provide an impedance source (Z-source) coupling the inverter to load, or another converter. Switches used in the inverter can be a combination of switching devices and diodes as anti-parallel combination. 
 \\ International Journal of Advanced Research in Electrical, Electronics and Instrumentation Engineering \\ (An ISO 3297: 2007 Certified Organization)}

\section{Vol. 3, Issue 8, August 2014}

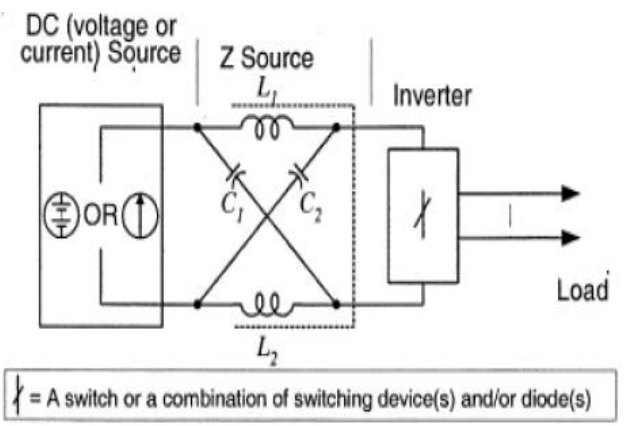

Fig.1.3 General Structure of the Z-source inverter

\section{II.PROPOSED IMPROVED TRANS-Z-SOURCE INVERTER}

The improved inverter as shown in fig.1.4 was proposed in order to accomplish single stage power conversion with buck-boost abilities in the improved inverter, both of the power switches in a leg can be turned on the at the same time, which eliminates dead time and significantly improves the reliability while reducing the output waveform distortion.

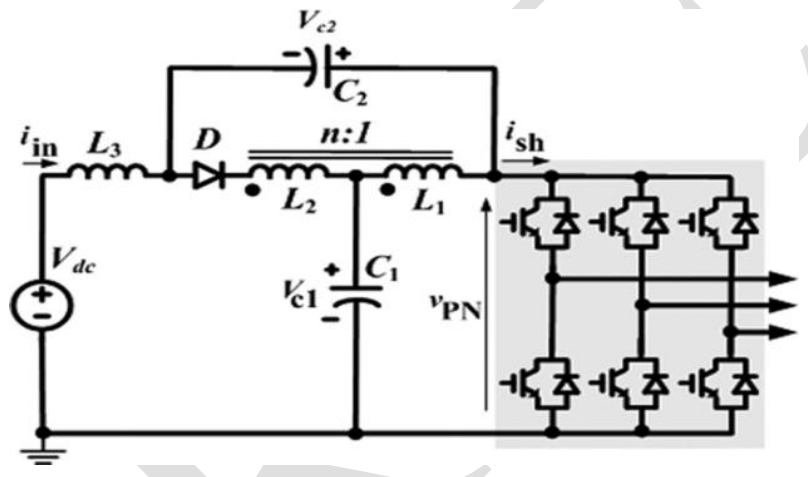

Fig.2.1 Improved trans-Z-source inverter with continuous input current and boost inversion capability

The input DC current is continuous. It provides resonant current suppression, unlike the trans-Z-source inverter topology because no current flows to the main circuit at start up. Only one inductor and one capacitor are added, and a higher boost factor can be obtained with the same turn ratio and component count compared to the LCCT-Z-source inverters and the conventional trans-Z-source and trans-quasi-Z-source inverters with the LC input filter.

\section{III.OPERATION}

The improved inverter has extra shoot through zero states in additional to the traditional six active and two zero states in a classical $\mathrm{Z}$ source inverter. Thus operating principles of the improved inverter are similar to those of the classical $\mathrm{Z}$-source inverters. For the purpose of analysis, the operating states are simplified in to shoot through and non shoot through states. The equivalent circuits of the improved trans-Z-source inverter, where the two windings are replaced by an ideal transformer and a mutual inductance (Lm). In the shoot through mode, the inverter side is shorted by both upper and lower switching devices of any phase leg. 
 \\ International Journal of Advanced Research in Electrical, Electronics and Instrumentation Engineering \\ (An ISO 3297: 2007 Certified Organization)}

Vol. 3, Issue 8, August 2014

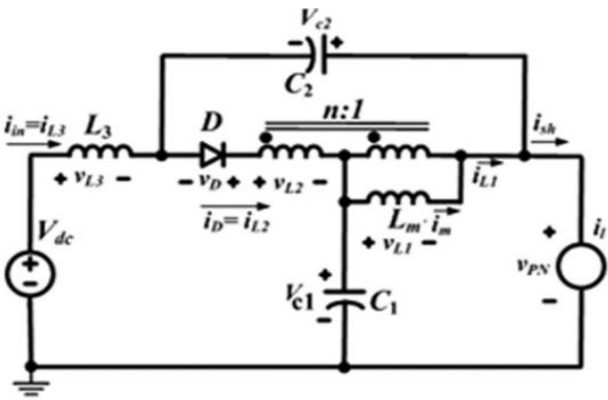

Fig.2.2. Equivalent circuit of improved trans-Z-source inverter

The improved trans-Z-source inverter uses a lower transformer turn ratio than the trans-Z-source/quasi-Z-source inverter to produce the same boost factor. When $n=0, B=1 /(1-2 D)$, the improved inverter becomes the classical $Z$ source inverter. When $n>1$, the boost ability of the improved trans-Z-source inverter is higher than that of the improved trans-Z-source inverter and trans-quasi-Z-source inverters.

\section{RESULT AND DISCUSSION}

\section{A.PROPOSED TRANS-Z-SOURCE INVERTER IN OPEN LOOP}

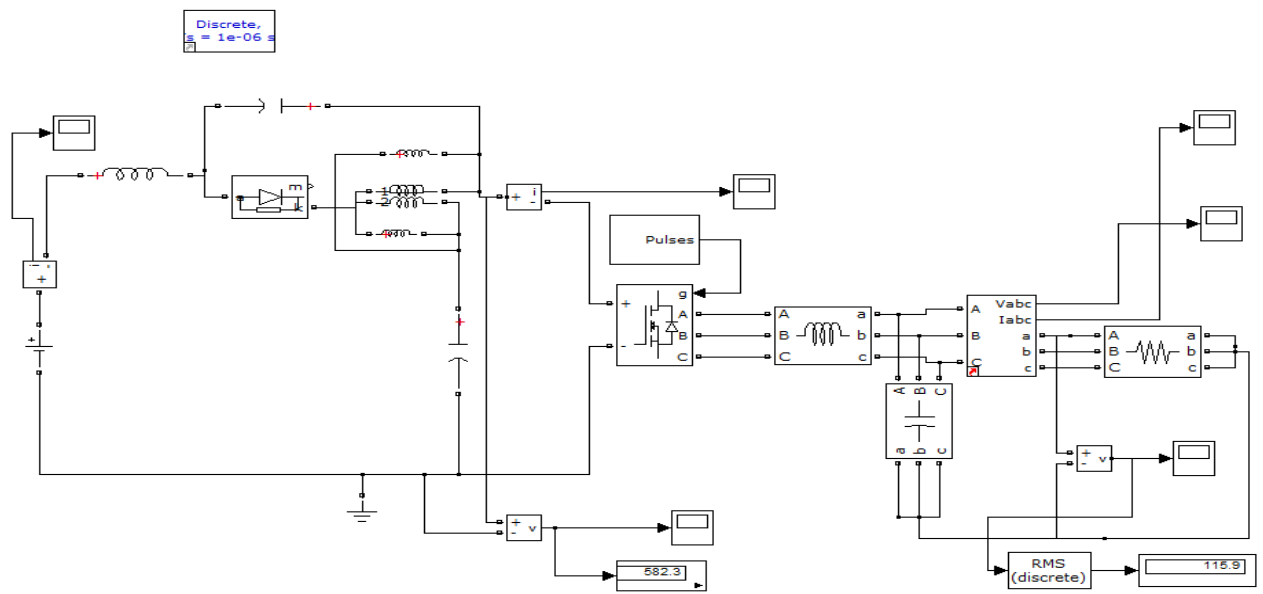

Fig.4.1.Simulation diagram of the proposed Trans-Z-source inverter in open loop

The above fig.4.1 represents the simulation diagram of improved trans-Z-source inverter in open loop and corresponding output voltage and current waveforms are shown in below diagrams.

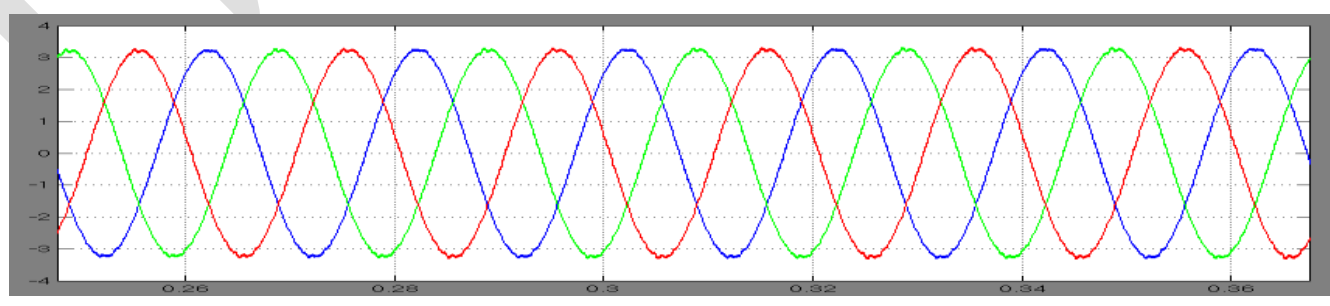

Time $(\mathrm{ms})$

Fig.4.2 Simulation diagram of the output current waveform

The fig.4.2 shows the simulation diagram of output current waveform time vs amplitude of current which shows continuous current waveform. 


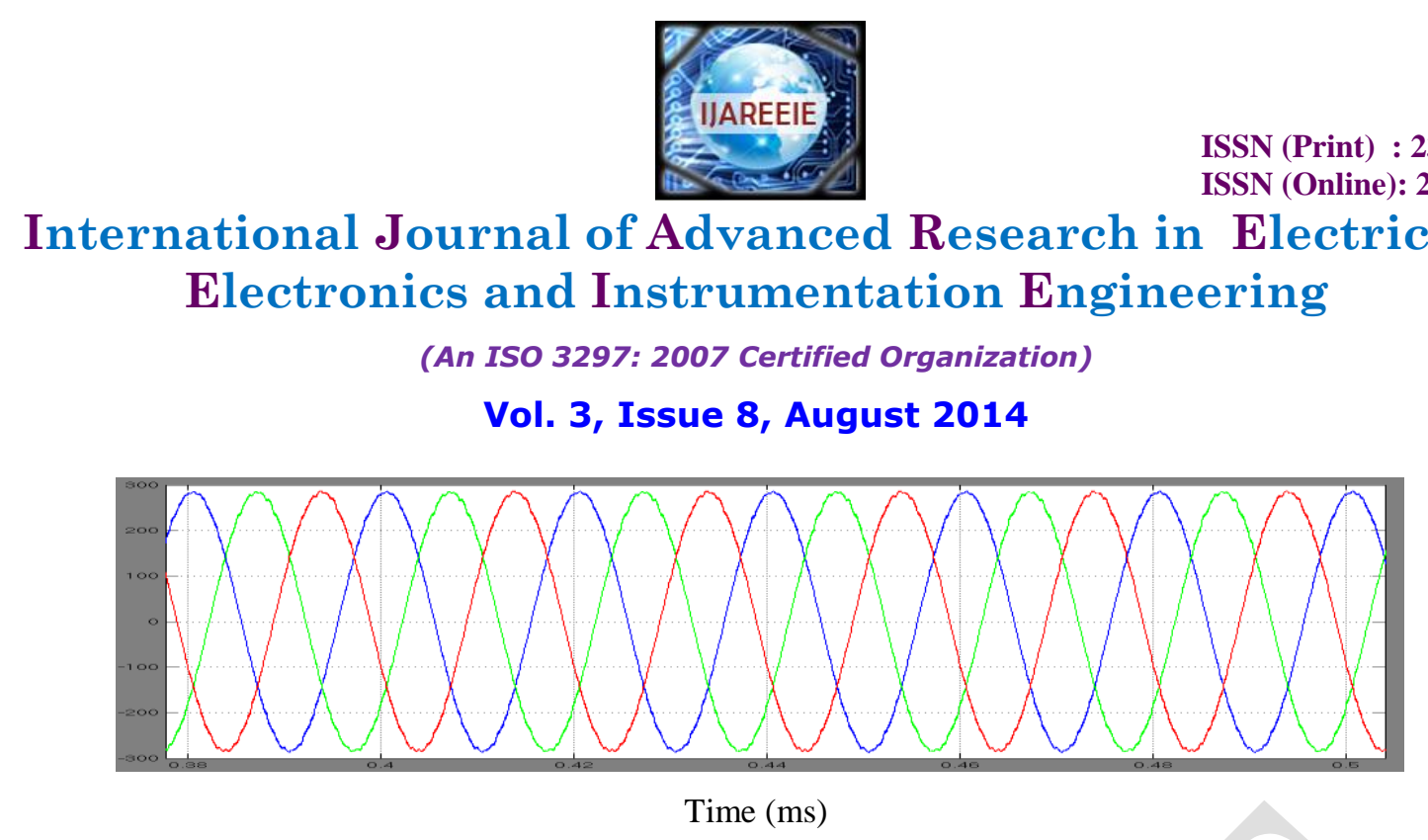

Fig.4.3 Simulation diagram of the output voltage waveform

Fig 4.3 shows the simulation diagrams of the output voltage waveforms time vs amplitude of voltage which is improved upon simulation.

\section{B.SIMULATION DIAGRAM OF THE PROPOSED TRANS-Z-SOURCE INVERTER WITH ASYNCHRONOUS MOTOR}

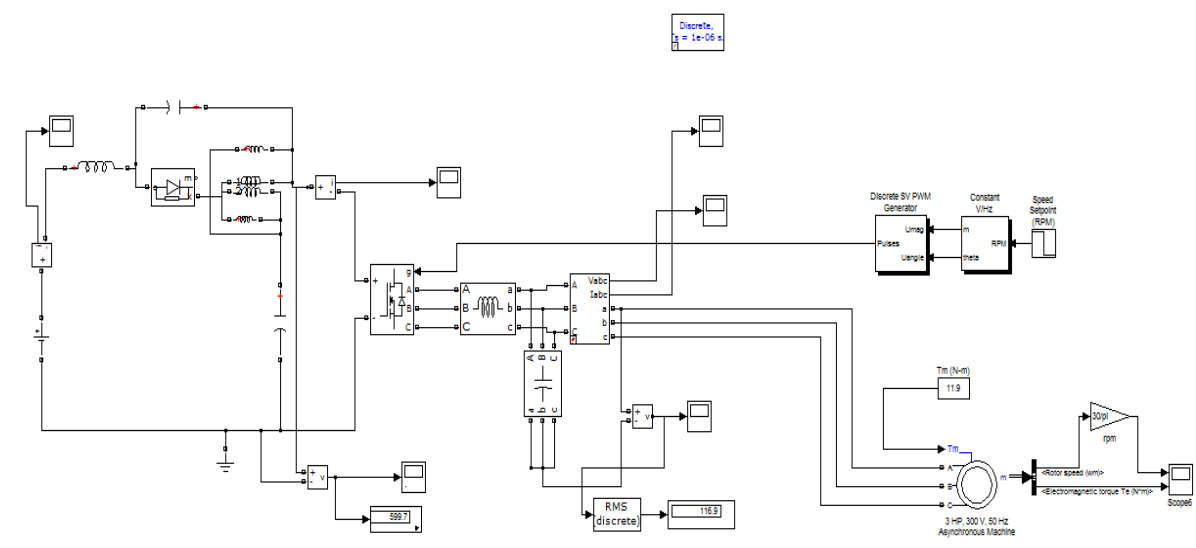

Fig.4.4 Simulation diagram of the proposed trans-Z-source inverter with asynchronous motor

The above fig.4.4 shows the simulation diagram of improved trans-Z-source inverter with asynchronous motor in closed loop.The corresponding output voltage and current waveforms are shown in below diagrams.

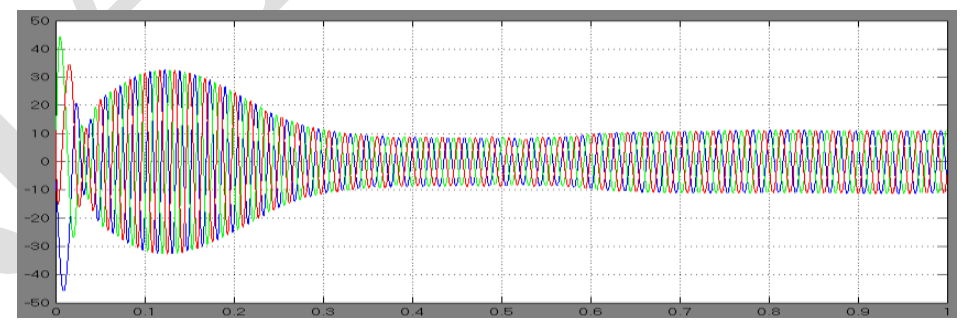

$$
\text { Time (ms) }
$$

Fig.4.5 Output current waveform of asynchronous motor

The fig.4.5 shows the output current waveform of asynchronous motor time vs amplitude of current of proposed transZ-source inverter in closed loop. 


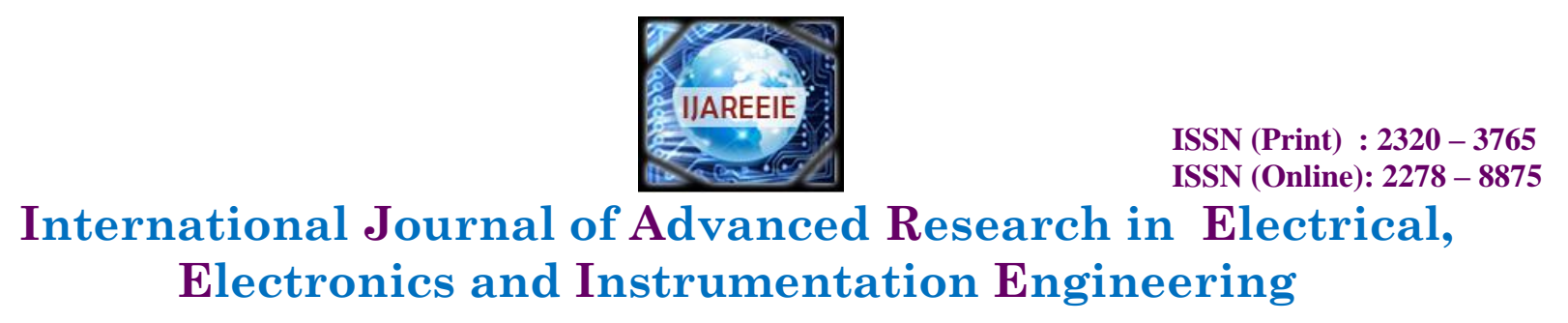

(An ISO 3297: 2007 Certified Organization)

Vol. 3, Issue 8, August 2014

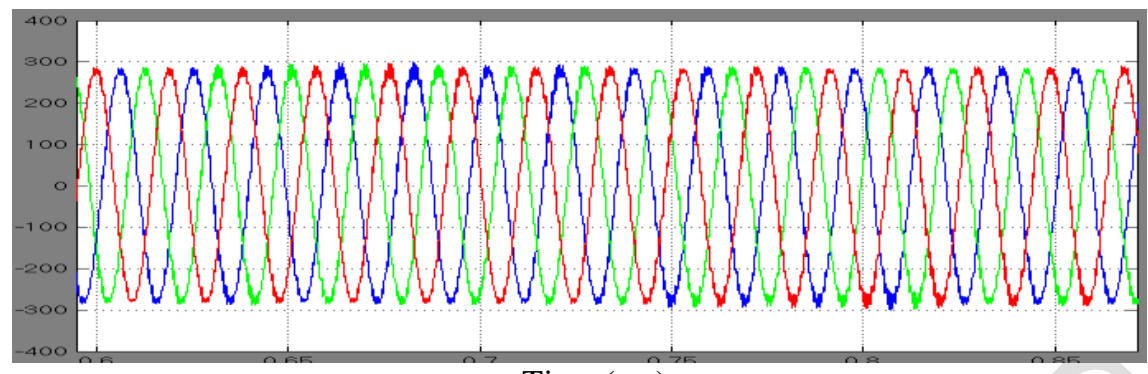

Time (ms)

Fig.4.6 Output voltage waveform of asynchronous motor

The fig.4.6 shows the output voltage waveform of asynchronous motor time vs amplitude of voltage of proposed transZ-source inverter in closed loop.

\section{V.CONCLUSION}

A new topology was proposed to improve the trans-Z-source inverter with the following main characteristics: high boost voltage inversion ability, continuous input current and resonant suppression at start up. The conventional trans-Zsource and trans-quasi-Z-source inverters, for the same transformer turn ratio, input and output voltage, the improved inverter has a higher modulation index with reduce voltage stress on the DC link, lower current stress flow to the transformer winding and diode and lower current ripple if the modulation is kept fixed, the improved inverter uses a lower transformer turn ratio to produce the same input and output voltage compared to the conventional trans-Zsource/quasi-Z-source inverters. As a result, the size and weight of the transformer in the improved inverter can be reduced. The system can be improved to have application such as fuel cell EHV.

\section{REFERENCES}

[1] F.Z. Peng, “Z-source inverter," IEEE Trans. Ind. Appl., vol.39, no.2, pp.504-510, Mar/Apr. 2003.

[2] J. B. Liu, J. G. Hu and L.Y.Xu, "Dynamic modeling and analysis of Z-source converter derivation of AC small signal model and design oriented analysis," IEEE Trans. Power Electron, vol.22, no.5, pp.1786-1796, sep.2007

[3] P. C. Loh, D.M.Vilathgamuwa, G.J.Gajaanayake, Y.R.Lim, and C.W.Teo, "Transient modeling and analysis of pulse—width modulated Zsource inverter," IEEE Trans. Power Electron, vol.22, no.2, pp.498-507, Mar.2007.

[4] M.Shen, J.Wang, A.Joesph, F.Z.Peng, L.M.Toibert, and D.J.Adams, "Constant boost control of the Z-source inverter to minimize current ripple and voltage stress,” IEEE Trans. Ind. Appl., vol.42, no.3, pp. 770-778, May/Jun.2006.

[5] O. Ella ban, J.V. Mierlo, and P Lataire, “A DSP based dual loop peak dc-link voltage strategy of the Z-source inverter," IEEE Trans. Power Electron, vol. 27, no. 9, pp. 4088-4097, sep.2012

[6] M. Adamowicz, R. Strzelecki, F.Z. Peng, J. Guzinski and H.A.Rub, "New type LCCT-Z-source inverters," in proc. Eur. Conf. Power Electron. Appl., 2011, pp. 1-10.

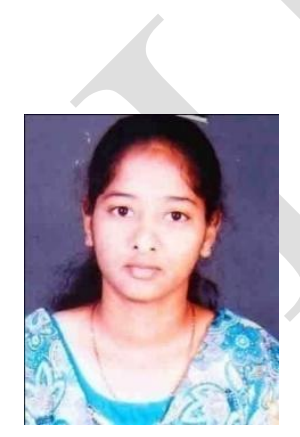

\section{BIOGRAPHY}

Subhashini received B.Tech degree in Electrical and Electronics Engineering from Jawaharlal Nehru University, Anatapur, India in 2012. Currently she is pursuing M.Tech in Power Electronics in Sreenivasa Institute of Technology and Management Studies, Chittoor, Andhra Pradesh, India. Her research areas of interests are development in Power Electronics and Motor control. 


\section{9 \\ ISSN (Print) : 2320 - 3765 \\ ISSN (Online): 2278 - 8875 \\ International Journal of Advanced Research in Electrical, Electronics and Instrumentation Engineering \\ (An ISO 3297: 2007 Certified Organization) \\ Vol. 3, Issue 8, August 2014}

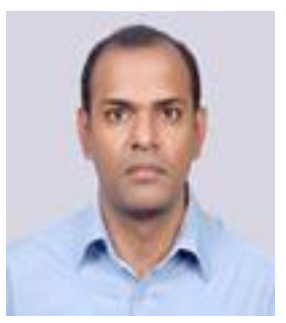

M.S.Giridhar received M.Tech degree in Electrical and Electronics Engineering from REC Calicut in 2002 and currently he is pursuing his Ph.D in J.N.T.U, Kakinada. He is working as an associate professor in the department of Electrical Engineering in Sreenivasa Institute of Technology and Management Studies, Chittoor, Andhra Pradesh, India. His research area of interests is computer techniques for Distribution Automation. 